\title{
HUBUNGAN POLA ASUH ORANG TUA DENGAN KEJADIAN PERNIKAHAN USIA DINI PADA WANITA USIA MUDA DI DESA MALAUSMA KECAMATAN MALAUSMA KABUPATEN MAJALENGKA
}

\author{
${ }^{1}$ Merissa Laora Heryanto, ${ }^{2}$ Ai Nurasiah, ${ }^{3}$ Agneu Nurbayanti \\ ${ }^{1,2,3}$ STIKes Kuningan \\ merissalaora@gmail.com
}

\begin{abstract}
Abstrak
Secara nasional pernikahan dini dengan pasangan usia di bawah 16 tahun sebanyak 26,95\%. Data Desa Malausma terdapat 23 orang (30\%) yang menikah usia dini. Tujuan penelitian untuk mengetahui hubungan pola asuh orang tua dengan kejadian pernikahan usia dini pada wanita usia muda di Desa Malausma. Metode penelitian menggunakan rancangan cross sectional. Teknik pengambilan sampel menggunakan total sampling dengan jumlah sampel sebanyak 75 responden. Analisa data menggunakan uji Chi Square. Hasil analisis bivariat menunjukan bahwa terdapat korelasi antara pola asuh orang tua dengan kejadian pernikahan usia dini pada wanita usia muda dengan nilai $\mathrm{p}=0,000$. Data penelitian menunjukan bahwa responden dengan pola asuh otoriter yang menikah usia dini terdapat 8 orang $(53,3 \%)$, responden dengan pola asuh demokratis yang menikah usia dini terdapat 1 orang $(2,9 \%)$ dan responden dengan pola asuh permisif yang menikah usia dini terdapat 14 orang $(53,8 \%)$. Kesimpulan: terdapat hubungan antara pola asuh orang tua dengan kejadian pernikahan usia dini pada wanita usia muda di Desa Malausma Kecamatan. Diharapkan orang tua bersikap bijak dalam membimbing dan mengarahkan anak, sehingga anak bisa memilih keputusan dengan tepat khususnya dalam masalah pernikahan.
\end{abstract}

Kata kunci $\quad$ :Pola asuh, pernikahan usia dini

\section{Pendahuluan}

Pernikahan usia dini merupakan pernikahan yang dilakukan oleh seseorang yang memiliki umur yang relatif muda. Umur yang relatif muda tersebut yaitu usia pubertas usia antara 10-19 tahun (Desiyanti, 2015). Pernikahan usia dini berdampak buruk pada kesehatan, psikis dan sosial. Hal ini juga dapat memutuskan pendidikan karena terjadinya pernikahan dini mudah 
JOURNAL OF MIDWIFERY CARE :

VOL. 01 NO. 01, DESEMBER 2020

DOI: $\underline{10.34305 / j m c . v 1 i 1.198}$

menimbulkan kawin cerai, sedangkan pada bayi akan menimbulkan Berat Badan Bayi Rendah (BBLR), cacat bawaan hingga kematian bayi (Khilmiyah, 2014).

Berdasarkan laporan BKKBN (2012) menyebutkan, bahwa di Indonesia pernikahan dini sekitar $12-20 \%$ yang dilakukan oleh pasangan baru. Secara nasional pernikahan dini dengan pasangan usia di bawah 16 tahun sebanyak 26,95\%. Pernikahan di bawah usia 16 tahun di Indonesia yaitu mencapai $25 \%$ dari jumlah pernikahan yang ada (Badan Pusat Statistik, Badan Koordinasi Keluarga Berencanan Nasional, Departemen Kesehatan, \& Macro Internasional, 2013).

Berdasarkan hasil analisis data perkawinan usia anak, Jawa Barat berada di peringkat ke-9 dengan prevalensi terendah sebesar 28\%, prevalensi tertinggi sebesar $33,1 \%$ dan rata-rata 30,5\% (Mubasyaroh, 2016), sedangkan data sekunder dari Kantor Urusan Agama (KUA) Kecamatan Malausma Kabupaten Majalengka, pada tahun 2017 didapatkan 462 pasangan yang menikah, adapun remaja perempuan yang menikah pada usia 16-17 tahun sebanyak 65 orang $(14,1 \%)$ dan dengan usia 18-19 tahun sebanyak 84 orang $(18,2 \%)$, sedangkan Desa Malausma didapatkan 77 pasangan yang menikah, adapun remaja perempuan yang
Ciptaan disebarluaskan di bawah

Lisensi Creative Commons Atribusi-

NonKomersial-BerbagiSerupa 4.0 Internasional. menikah dengan usia 16-17 tahun sebanyak 10 orang dan 18-19 tahun sebanyak 13 orang, dengan demikian maka jumlah keseluruhan perempuan yang menikah pada usia dini di Desa Malausma diperkirakan mencapai 23 orang (30\%).

Berdasarkan hasil penelitian Purwaningsih \& Setyaningsih, (2015) dari 40 responden sebagian besar pola asuh demokratis tidak melakukan pernikahan usia dini, seluruhnya pola asuh permisif melakukan pernikahan usia dini dan sebagian besar pola asuh otoriter melakukan pernikahan usia dini. Hasil uji statistik didapatkan ada hubungan pola asuh orang tua dengan kejadian pernikahan usia dini. Purwaningsih menyimpulkan bahwa hampir sebagian besar orang tua kurang memperhatikan kesehatan dan pendidikan anak-anaknya.

Berdasarkan uraian diatas, peneliti tertarik melakukan penelitian untuk mengetahui hubungan pola asuh orang tua dengan kejadian pernikahan usia dini pada wanita usia muda di Desa Malausma Kecamatan Malausma Kabupaten Majalengka Tahun 2018.

\section{Metode}

Penelitian ini menggunakan metode cross-sectional, dilakukan tahun 2018 di E-ISSN 2774-4167 | 79 
JOURNAL OF MIDWIFERY CARE :

VOL. 01 NO. 01, DESEMBER 2020

DOI: $\underline{10.34305 / j m c . v 1 i 1.198}$

Desa Malausma Kecamatan Malausma Kabupaten Majalengka pada perempuan yang sudah menikah dan menetap di Desa Malausma dengan menggunakan total sampling yang berjumlah 75 responden.

Hasil

Hubungan Pola Asuh Orang Tua dengan Kejadian Pernikahan Usia Dini Tabel 1.Distribusi Frekuensi Responden

\begin{tabular}{lcc}
\hline \multicolumn{1}{c}{ Variabel } & Frekuensi (n) & Persentase (\%) \\
\hline Pola Asuh Orang Tua & 15 & 20,0 \\
Otoriter & 34 & 45,3 \\
Demokratis & 26 & 34,7 \\
Permisif & & \\
Pernikahan Usia Dini & 23 & 30,7 \\
Ya & 52 & 68,3 \\
Tidak
\end{tabular}

Pada tabel 1 dapat diketahui bahwa melakukan pernikahan usia dini sebanyak 52 dari 75 responden, sebagian besar tidak responden $(69,3 \%)$.

Tabel 2.Hubungan antara Pola Asuh Orang Tua dengan Kejadian Pernikahan Usia Dini

\begin{tabular}{|c|c|c|c|c|c|c|c|c|}
\hline \multirow{2}{*}{\multicolumn{2}{|c|}{ Variabel }} & \multicolumn{4}{|c|}{ Pernikahan Usia Dini } & \multirow{2}{*}{\multicolumn{2}{|c|}{ Total }} & \multirow{3}{*}{$\begin{array}{l}\text { P value } \\
\text { CI 95\% }\end{array}$} \\
\hline & & \multicolumn{2}{|c|}{ Ya } & \multicolumn{2}{|c|}{ Tidak } & & & \\
\hline & & $\mathbf{N}$ & $\%$ & $\mathbf{N}$ & $\%$ & $\mathbf{N}$ & $\%$ & \\
\hline \multirow{3}{*}{ Pola Asuh } & Otoriter & 8 & $53,3 \%$ & 7 & $46,7 \%$ & & & \multirow{3}{*}{$\mathrm{p}=0,000$} \\
\hline & Demokratis & 1 & $2,9 \%$ & 33 & $97,1 \%$ & & & \\
\hline & Permisif & 14 & $53,8 \%$ & 12 & $46,2 \%$ & & & \\
\hline \multicolumn{2}{|c|}{ Total } & 23 & $100 \%$ & 52 & $100 \%$ & 75 & $100 \%$ & \\
\hline
\end{tabular}

Berdasarkan tabel 2 menunjukan bahwa responden dengan pola asuh otoriter yang menikah usia dini diperoleh sebanyak 8 orang $(53,3 \%)$, responden dengan pola asuh demokratis yang menikah usia dini sebagian kecil diperoleh 1 orang $(2,9 \%)$ dan responden dengan pola asuh permisif yang menikah usia dini sebesar 14 orang $(53,8 \%)$. 
JOURNAL OF MIDWIFERY CARE :

VOL. 01 NO. 01, DESEMBER 2020

DOI: $\underline{10.34305 / j m c . v 1 i 1.198}$

Berdasarkan hasil uji statistik dengan menggunakan uji Chi Square diperoleh nilai $p$ yaitu 0,000 dengan tingkat kemaknaan $\propto=0,05$ maka dapat disimpulkan bahwa, nilai $p<0,05$ artinya terdapat hubungan antara pola asuh orang tua dengan kejadian pernikahan usia dini pada wanita usia muda di Desa Malausma Kecamatan Malausma Kabupaten Majalengka Tahun 2018.

\section{Pembahasan}

Hubungan Pola Asuh Orang Tua dengan Kejadian Pernikahan

Melihat dari hasil statistik yang didapat dari penelitian menunjukan bahwa pola asuh orang tua memiliki hubungan yang bermakna dengan kejadian pernikahan usia dini. Hasil penelitian ini sesuai dengan Wahyuningsih \& Soimah, (2016) yang menyatakan bahwa ada hubungan tingkat kejadian pernikahan dini dengan peran orang tua dengan nilai signifikan $p=0,007$, karena orang tua merupakan faktor adanya perkawinan usia muda, dimana sudah menjadi budaya atau kebiasaan turuntemurun orang tua akan segera menikahkan anaknya jika sudah menginjak besar.

Berdasarkan hasil penelitian pada ibu yang pola asuh orang tuanya otoriter dan melakukan pernikahan usia dini, peneliti
Ciptaan disebarluaskan di bawah

Lisensi Creative Commons Atribusi-

NonKomersial-BerbagiSerupa 4.0 Internasional.

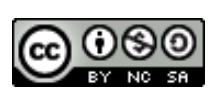

menegaskan hal ini disebabkan oleh adanya adat istiadat yang dimiliki desa Malausma. Berdasarkan hasil wawancara pada ibu dengan pola asuh orang tuanya otoriter dengan melakukan pernikahan usia dini, mereka mengatakan bahwa orang tuanya merasa khawatir jika menikahkan anaknya terlalu tua karena nantinya akan disebut sebagai perawan tua. Hal tersebut terjadi karena rendahnya pendidikan orang tua dan minimnya wawasan, sehingga masih menerapkan informasi dari budaya lama dan tidak mudah menerima hal yang baru.

Orang tua pada umumnya ingin cepat-cepat menikahkan anak gadisnya karena takut akan menjadi perawan tua. Kejadian ini tidak memikirkan nasib pendidikannya. Kultur di sebagian besar masyarakat Indonesia masih memandang hal yang wajar apabila pernikahan dilakukan pada usia anak-anak atau remaja karena hal tersebut sulit untuk dihilangkan dalam lingkungan masyarakat tersebut. Alasan yang diberikan responden mau menikah di usia dini, hal ini disebabkan oleh takut pada orang tua, hal ini terlihat dari hasil wawancara mengenai pada saat keluarga mengemukakan pendapat, jika responden tidak setuju dengan pendapat orang tua, mereka menyuruh responden untuk mengikuti pendapat mereka.

E-ISSN 2774-4167 | 81 
JOURNAL OF MIDWIFERY CARE :

VOL. 01 NO. 01, DESEMBER 2020

DOI: $10.34305 / j m c . v 1 i 1.198$
Ciptaan disebarluaskan di bawah

Lisensi Creative Commons Atribusi-

NonKomersial-BerbagiSerupa 4.0

Internasional.
Hasil wawancara mengenai Ketika anak melakukan kesalahan yang orang tua lakukan adalah selalu menghukum dengan keras tanpa toleransi karena merasa tidak nyaman cara terbaik menghindar hal tersebut maka responden menikah di usia dini. Hal ini sesuai dengan pendapat Dariyo, (2014) bahwa pola asuh otoriter adalah sentral artinya segala ucapan, perkataan maupun kehendak orang tua dijadikan patokan (aturan) yang harus ditaati oleh anakanaknya. Orang tua tidak segan-segan menerapkan hukuman yang keras kepada anak, cenderung menggunakan pendekatan yang bersifat diktator, menonjolkan wibawa, menghendaki ketaatan mutlak.

Teori yang diungkapkan oleh Adik dalam Aisyah, (2010) menyatakan bahwa pola asuh otoriter akan menghasilkan karakteristik anak yang tertutup, pendiam, penakut, tidak berinisiatif, suka melanggar norma, gemar menentang, berkepribadian lemah, cemas dan menarik diri. Perkawinan usia muda dapat berlangsung karena adanya sikap patuh dan atau menentang yang dilakukan remaja terhadap perintah orang tua. Hubungan dengan orang tua menentukan terjadinya perkawinan usia muda, dalam kehidupan sehari-hari sering ditemukan perkawinan remaja karena ingin melepaskan diri dari pengaruh lingkungan orang tua. Adapun pada pola asuh orang tua dengan otoriter tapi tidak menikah di usia dini, menurut data hal ini disebabkan oleh adanya latar belakang pola pengasuhan orang tua, pada saat orang tua responden masih muda selalu dididik dengan pola asuh otoriter, namun ternyata dengan pola asuh tersebut ibu menjadi disiplin dan menjadi sukses (Mubasyaroh, 2016). Hal ini terlihat pada hasil wawancara mengenai bagaimana cara orang tua dalam menerapkan disiplin atau aturan, mereka menjawab orang tua beranggapan bahwa dengan memberikan banyak aturan maka akan berperilaku sebagaimana mestinya.

Orang tua yang memberi banyak aturan akan membawa dampak pada pola asuh anaknya, dengan harapan agar anaknya menjadi orang sukses. Hal ini sesuai dengan pendapat Septiari, (2012) yang mengatakan bahwa salah satu faktor yang mempengaruhi pola asuh orang tua adalah adanya latar belakang pola pengasuhan orangtua.

Pola asuh orang tua demokratis yang menikah usia dini dari hasil data penelitian disebabkan oleh tingkat pendidikan responden yang rendah. Biasanya pada remaja apabila tidak melanjutkan pendidikan, maka akan pergi merantau untuk mencari pekerjaan. Namun disisi lain akan bertemu dengan lawan jenis yang pada E-ISSN 2774-4167 | 82 
JOURNAL OF MIDWIFERY CARE :

VOL. 01 NO. 01, DESEMBER 2020

DOI: $\underline{10.34305 / j m c . v 1 i 1.198}$

akhirnya berharap untuk melanjutkan ke jenjang pernikahan. Hal ini sesuai dengan pendapat Desiyanti (2015) mengatakan bahwa semakin rendah tingkat pendidikan, semakin mendorong berlangsungnya perkawinan usia muda. Hal ini sesuai dengan pendapat Rumekti (2016) yang menyatakan bahwa alasan melakukan pernikahan usia dini yaitu suka sama suka, alasan banyak anak-anak atau remaja yang memutuskan untuk menikah diusia dini karena mereka menginginkan untuk segera menikah yang hanya didasari rasa cinta tanpa memikirkan kebutuhan dan kehidupan setelah menikah. Meskipun demikian orang tua bersikap bijak, hal ini terlihat pada hasil wawancara menyatakan bahwa ketika membahas mengenai masa depan, maka tanggapan orang tua selalu memberikan arahan terkait masa depan, dan selalu mendiskusikannya dengan responden (Desiyanti, 2015).

Adapun pada responden dengan pola asuh orang tua demokratis tidak melakukan pernikahan usia dini, hal ini disebabkan oleh tingkat pendidikan orang tua yang tinggi. Hal ini terlihat pada hasil wawancara dalam hal pengambilan sebuah keputusan yang orang tua terapkan yaitu dengan mendiskusikan langsung pada responden ketika mereka akan mengambil sebuah keputusan orang tuanya. Hal ini sejalan
Ciptaan disebarluaskan di bawah Lisensi Creative Commons AtribusiNonKomersial-BerbagiSerupa 4.0 Internasional. dengan Septiari (2012) bahwa tingkat pendidikan dan pengetahuan orang tua serta pengalaman sangat berpengaruh dalam mengasuh anak. Pendidikan akan memberikan dampak bagi pola pikir dan pandangan orang tua dalam mendidik anaknya. Orang tua yang memiliki tingkat pendidikan dan wawasan yang tinggi akan memperhatikan dan merawat anak sesuai dengan usia perkembangannya dan akan menunjukkan penyesuaian pribadi dan sosial yang lebih baik yang akan membuat anak memiliki pandangan positif terhadap orang lain dan masyarakat. Penelitian telah menunjukkan bahwa ketika ibu memiliki pengetahuan yang lebih tinggi terhadap perkembangan anak, mereka menunjukkan tingkat keterampilan pengasuhan yang lebih tinggi, anak-anak mereka memiliki kemampuan kognitif yang lebih tinggi dan hanya memiliki sedikit masalah perilaku.

Berdasarkan hasil penelitian, responden dengan pola asuh permisif yang menikah usia dini disebabkan oleh pergaulan bebas. Pergaulan bebas tersebut terjadi karena berawal dari adanya kurangnya perhatian karena kesibukan yang dimiliki orang tua mengakibatkan anak mencari perhatian di luar. Hal ini terlihat dari hasil wawancara bahwa cara orang tua menyikapi pergaulan responden yaitu dengan E-ISSN 2774-4167 | 83 
JOURNAL OF MIDWIFERY CARE :

VOL. 01 NO. 01, DESEMBER 2020

DOI: $10.34305 /$ jmc.v1i1.198
Ciptaan disebarluaskan di bawah

Lisensi Creative Commons Atribusi-

NonKomersial-BerbagiSerupa 4.0

Internasional. membebaskan dalam bergaul dengan siapapun, dimanapun tanpa ada batasan. Kurangnya pengawasan dari orang tua berdampak pada anak yang beraktivitas tanpa pengawasan. Hal ini sesuai dengan pendapat Septiari (2012) yang menyatakan bahwa dengan pola asuh permisif, anak yang diberikan kesempatan sebebas-bebasnya untuk berbuat dan memenuhi keinginannya akan menjadikan anak tersebut tidak terkendali, tidak patuh dan tingkah laku agresif di luar lingkungan keluarga.

Informasi yang berasal dari media internet yang luas mempunyai berbagai informasi salah satunya informasi yang berdampak negatif dan mempengaruhi psikologis anak yang mengakibatkan anak hamil di luar nikah, agar tidak menimbulkan aib, maka salah satu jalan dilakukan pernikahan dengan usia yang masih dini. Hal ini sejalan dengan Khilmiyah, (2014) yang mengatakan bahwa semakin modern media massa berkembang secara canggih, hal ini banyak remaja menyalahgunakan media massa untuk hal-hal yang negatif sehingga remaja sekarang banyak yang melakukan pergaulan bebas, apabila keluarga kurang memiliki pilihan dalam menghadapi atau mengatasi masalah remaja seperti anak gadisnya melakukan perbuatan zina, maka anak gadis tersebut dinikahkan sebagai jalan keluarnya.

Berdasarkan penelitian, responden dengan pola asuh orang tua yang permisif yang menikah usia dini disebabkan karena responden melanjutkan pendidikan ke jenjang yang lebih tinggi yang pada akhirnya waktu responden pada masa tersebut digunakan untuk melanjutkan pendidikan. Hal ini terlihat pada hasil wawancara mengatakan bahwa perilaku orang tua ketika membahas perihal pernikahan, orang tua membebaskan menikah kapanpun responden inginkan. Hal ini sesuai dengan pendapat Sardi, (2016) yang mengatakan bahwa peran tingkat pendidikan berhubungan erat dengan pemahaman keluarga tentang kehidupan berkeluarga, jika sikap permisif ini tidak berlebihan dia akan mendorong anak menjadi cerdas, mandiri dan berpenyesuaian sosial yang baik dengan teman sebaya dan saudaranya. Sikap ini juga menumbuhkan rasa percaya diri, kreativitas dan sikap matang (Ahmadi, 2014).

Pernikahan usia dini salah satu faktor penyebabnya adalah pola asuh orang tua, menurut Hadisiswantoro (2012) beberapa hal yang dapat dilakukan orang tua dalam mendidik anak adalah berikan perhatian dan pujian, jalinlah komunikasi yang baik, E-ISSN 2774-4167 | 84 
JOURNAL OF MIDWIFERY CARE :

VOL. 01 NO. 01, DESEMBER 2020

DOI: $\underline{10.34305 / j m c . v 1 i 1.198}$

berhati-hatilah dengan harapan anda kepada anak karena membuat anak stres apabila tidak sanggup memenuhi harapan yang tidak realistis, tingkatkan rasa percaya diri anak, berikan waktu yang berkualitas, yakinkan bahwa anda mengasihinya, berikan aturan dengan konsisten, jadilah teladan yang baik dan jadilah orang tua yang fleksibel.

\section{Kesimpulan}

Terdapat hubungan antara pola asuh orang tua dengan kejadian pernikahan usia dini pada wanita usia muda di Desa Malausma Kecamatan Malausma Kabupaten Majalengka Tahun 2018 dengan nilai $p=0,000$.

\section{Saran}

Orang Tua yang Memiliki Pola Asuh Otoriter dan Permisif disarankan untuk menerapkan pola asuh demokratis dalam mendidik anak sehingga anak bisa bersikap bijak dalam menjalankan kehidupan. menghargai pendapat dan keinginan anak serta mendiskusikan hal yang akan diputuskan merupakan tugas orang tua sebagai pembimbing dan mengarahkan sehingga mereka bisa memilih dan mengambil keputusan yang tepat.
Ciptaan disebarluaskan di bawah

Lisensi Creative Commons Atribusi-

NonKomersial-BerbagiSerupa 4.0 Internasional.

\section{Daftar Pustaka}

Ahmadi, A. (2014). Psikologi Belajar. Jakarta: Rineka Cipta.

Aisyah, S. (2010). Pengaruh pola asuh orang tua terhadap tingkat agresivitas anak. Jurnal Medtek, 2(1). http://repository.umy.ac.id

Badan Pusat Statistik, Badan Koordinasi Keluarga Berencanan Nasional (BKKBN), Departemen Kesehatan, \& Macro Internasional. (2013). Survei Demografi dan Kesehatan Indonesia 2012. https://doi.org/10.1111/j.14710528.2007.01580.x

Dariyo, A. (2014). Psikologi Perkembangan Dewasa Muda. Jakarta: Grasindo.

Desiyanti, I. W. (2015). Faktor-faktor yang berhubungan terhadap pernikahan dini pada pasangan usia subur di Kecamatan Mapanget Kota Manado. Jikmu, 5(3), 270-280.

Hadisiswantoro, Y. (2012). Anda Orang Tua Bodoh Atau Pintar?. Yogyakarta: Andi Publisher.

Khilmiyah, A. (2014). Pandangan Remaja Dan Orang Tua Terhadap Pernikahan Dini Dalam Membangun Keluarga Di Kabupaten Bantul. Universitas Muhammadiyah Yogyakarta. http://repository.umy.ac.id/bitstream/h andle/123456789/3574/8.

PERNIKAHAN DINI \%2B abstrak.pdf?sequence $=1$ \&isAllowed $=\mathrm{y}$

Mubasyaroh, M. (2016). Analisis Faktor Penyebab Pernikahan Dini Dan Dampaknya Bagi Pelakunya. YUDISIA: Jurnal Pemikiran Hukum Dan Hukum Islam, 7(2), 385-411. 
JOURNAL OF MIDWIFERY CARE :

VOL. 01 NO. 01, DESEMBER 2020

DOI: $\underline{10.34305 / j m c . v 1 i 1.198}$

Purwaningsih, E., \& Setyaningsih, R. T. (2015). Hubungan Pola Asuh Orang Tua Dengan Kejadian Pernikahan Usia Dini Di Desa Jambu Kidul, Ceper, Klaten. INVOLUSI Jurnal Ilmu Kebidanan, 4(7), 1-12.

Rumekti, M. M. (2016). Peran Pemerintah Daerah (Desa) Dalam Menangani Maraknya Fenomena Pernikahan Dini Di Desa Plosokerep Kabupaten Indramayu. E-Societas, 5(6). http://journal.student.uny.ac.id/ojs/ind ex.php/societas/article/view/4026/3684

Sardi, B. (2016). Faktor-faktor pendorong pernikahan dini dan dampaknya di desa
Ciptaan disebarluaskan di bawah

Lisensi Creative Commons Atribusi-

NonKomersial-BerbagiSerupa 4.0 Internasional. mahak baru kecamatan sungai boh kabupaten malinau. Ejournal SosiatriSosiologi, 4(3), 194-207.

Septiari, B. B. (2012). Mencetak balita cerdas dan pola asuh orang tua. Yogyakarta: Nuha Medika.

Wahyuningsih, S. A., \& Soimah, N. (2016). Hubungan Tingkat Kejadian Pernikahan Dini dengan Peran Orang Tua pada Perempuan di Bawah Usia 21 Tahun di Desa Sidoarum Kecamatan Godean Kabupaten Sleman Yogyakarta. Universitas' Aisyiyah Yogyakarta. 